rendering of the account, and that through some error the collectors in his diocese had demanded payment on the assessment known as the taxation of Pope Nicholas from spiritualities as well as temporalities, which was not according to the terms of the grant. ${ }^{1}$

The disposal of the balance of this ecclesiastical tenth is obscure. Edward I sent messengers to the convocation which met at the New Temple on 25 June 1298 to ask for the rest for the defence of the kingdom and the church. ${ }^{2}$ Convocation assented that the money should be granted for this purpose in time of peril, but maintained that they could not now agree to it without the consent of the Pope. ${ }^{3}$ At the same time they received his request that prayers should be offered throughout the kingdom for his safety and success in his war against the Scots. ${ }^{4}$ The balance remained in the possession of the treasurers at the New Temple, and on 10 January they received a mandate from the archbishop to pay $£ 1,8336 s$. $8 d$. to Italian merchants for the use of the messengers who had been sent to prosecute some business for the province of Canterbury at the papal curia. ${ }^{5}$

Rose Graham.

\title{
The Administrative Divisions of the Mendicant Orders in England
}

$\mathrm{E}_{\Delta \mathrm{CH}}$ of the four Mendicant Orders divided the English province into areas or groups of convents for certain purposes.

Among the Franciscans these areas were called custodies; the system was universal throughout the order and dated from the earliest times. The custodian held office for a number of years and his functions may be described as those of a localized provincial minister and a permanent visitor. The custodians of each province elected one of their number to represent them at the general chapter; probably all custodians had the right to attend the provincial chapter either in person or by deputy. ${ }^{6}$ In every custody one convent had to be assigned for the reception and training of novices. In England the custody acquired a special importance as an educational area, each custody maintained a special school of theology $;^{7}$ candidates for degrees at the universities were chosen from friars who had lectured at these schools, and it is probable that the custom which prevailed in the

1 Rejister of Simon de Gandavo, pp. 73, 74, 117-10.

- Reg. Winchelsey, fo. 245 ; Wilking, Concilia, ii. 236.

- Rog. Winchelsey, fo. 245, 310 ; Wilkins, Concilia, ii. 237.

- Rejister of Bimon de Gandawo, pp. 9, 10.

- Reg. Wincholsoy, fo. 257 '.

- CE. 'Statute Prov. Aquitaniao' in Archioum Franciscarkn Historierm, vii. 477, 480 ; but cf, ibid., p. 478.

I Bull. Frane., vi. 30. 
province of France - that only those friars who had distinguished themselves as students in their custody should be sent to study at Paris 1-applied mutatis mutandis to England.

The list of the seven Franciscan custodies in England has been printed several times, but is reprinted here for the sake of completeness. The following list is taken from Clyn's annals and appears to have been issued by the general chapter of Perpignan in 1331.2 I add in brackets the names of houses founded later in the fourteenth century and included in the list given by Bartholomew of Pisa (c. 1385).

I. Custody of London containing eight (nine) houses: London, Salisbury, Canterbury, Winchelsea, Southampton, Lewes, Winchester, Chichester, (Ware).

II. Custody of Oxford containing eight houses : Oxford, Reading, Bedford, Stamford, Nottingham, Northampton, Leicester, Grantham.

III. Custody of Bristol contsining nine houses: Bristol, Gloucester, Hereford, Carmarthen, Cardiff, Bridgewater, Exeter, Dorchester, Bodmin.

IV. Custody of Cambridge containing eight (nine) houses : Cambridge, Norwich, Bury St. Edmunds (or Babwell), King's Lynn, Yarmouth, Ipswich, Colchester, Dunwich, (Walsingham).

V. Custody of Worcester containing nine houses: Worcester, Coventry, Lichfield, Stafford, Preston, Shrewsbury, Chester, Llanfaes, Bridgenorth.

VI. Custody of York containing seven houses: York, Lincoln, Beverley, Doncaster, Boston, Grimsby, Bcarborough.

VII. Custody of Newcastle containing nine houses: Newcastle, Richmond, Hartlepool, Carlisle, Berwick, Roxburgh, Haddington, Dundee, Dumfries.

In the Dominican order, where the administrative divisions of the provinces or groups of convents were called generally 'visitations', or sometimes 'nations', either the customs were more various or the development later than in the Franciscan order. A visitor was appointed every year to visit and report on each visitation to the provincial chapter : he was not a permanent head of the visitation as the Franciscan custodian was head of the custody. In the province of Provence during the thirteenth century the number of visitors each year was generally eight, but varied from seven to eleven; the usual number of convents visited by each visitor was four, and the grouping of the convents was continually changed. No organic 'visitation' had yet grown up. The Roman province at the end of the thirteenth century was divided into four fixed groups. In Spain, between 1250 and 1300 , the grouping of the convents followed national or provincial divisions. ${ }^{8}$ Similarly the province of Germeny was divided in

- Archivum Pranciscanum Historicum, vii. 497.

- Beo my Studies in Englieh Pranciacax Biotory, opp. vi.

- For all thew weo Donein, Acta Capitulorum Protincialium (1885). 
1303 into four 'nations', and the province of Saxony in 1308 into eight ' nations'.' It seems natural to connect these organic visitations or nations with the decree of the general chapter of Bologna in 1275 authorizing provincial priors to divide their provinces into ' vicariae '? At the head of each 'vicaria' 'was a vicar, who, though appointed every year, had a more permanent connexion with the vicaria, visitatio, or natio than the visitor appointed for the express purpose of visiting. Though the vicar in this sense is not much in evidence, it is clear that the permanent groups of convents were not merely the sphere of action of a visitor, but were associated also for other purposes, and developed characteristics, rights, and powers of their own.

The provincial records of the Dominican province of England have been lost, and we are thrown back on the general records of the order, especially the registers of the masters general, so far as these are extant for periods when, for some reason or other, the master general intervened in the local affairs of the province. In 1393 the mester general instituted Thomas Palmer as visitor of the two visitations of London and the March (or Oxford), and William Baktorp as visitor of the two visitations of Cambridge and York. At the same time he assigned two friars to Cambridge to lecture on the Sentences with a view to their promotion to the doctorate on behalf of the nations or visitations of Cambridge and Oxford, and two friars to Oxford on behalf of those of Cambridge and York. ${ }^{3}$ From these and similar entries it appears that normally each visitation in turn had the right to provide the lecturers at the two universities: whether they were chosen by the provincial chapter on the reports of the visitors or by the visitations directly is not clear. In 1397 we find :

On 15th September the following were'made vicars: in the visitation of Oxford friar John Bromzerd, master; in the visitation of Cambridge friar Richard Bachon, master ; in the visitation of London friar William Brostumber, master; in the visitation of York friar William Helmeslay, master."

Only one list of the convents belonging to each visitation has yet been discovered and that is incomplete. It is bound up as a fly-leaf in MS. Q. 93 in the Worcester Cathedral Library and the lower part of the leaf has been cut away to suit the size of the book. The date is fifteenth century. The inclusion of Langley Regis in the visitation of Cambridge suggests that it was later than 1426 when the general chapter reversed a previous decision and assigned that convent to Cambridge, but there was an appeal

\footnotetext{
- Los and Reichert, Qwellen und Forschungen zur Gesehichte des Domirikancrorders in Deutochland, i. 5 ; iv. 12.

Hon. Ord. Praed. Hist., iii. 177.

- Brit. Mos., Addit. MS. 32446, f. 2 ; of. ff. $4^{4}, 6$.

- Ibid. 1. $7^{\mathrm{b}}$.
} 
to the pope and the final decision is not known. 1 The document is printed in Floyer and Hamilton's Catalogue of Manuscripts in the Chapter Library of Worcester Cathedral. I give only the visitations and convents.

Visilation of London: convents of London, Sarum, Exeter, Canterbury, Winchester, Bristol, ...

Visitation of York: convents of York, Lincoln, Newcastle on Tyne, Lancaster, Scarborough, Yarm, Carlisle, ... .

Visitation of Oxford: convents of Oxford, Gloucester, Salop, Hereford ('Harford'), Northampton, Warwick, Newcastle under Lyme, Brecon, ...

Visitation of Cambridge : convents of Cambridge, Norwich, Stamford, Langley Regis, Lynn, Sudbury, Dunstable, . . .

The list only includes twentyeight convents: the remaining twenty-six convents are probsbly to be assigned as follows : to London the convente of Arundel, Chichester, Guildford, Ilchester, Melcombe Regis, Truro, Wilton, and Winchelsea ; to York those of Bamburgh, Beverley, Boston (?), Doncaster, Pontefract ; to Oxford those of Bangor, Cardiff, Chester, Derby, Haverfordwest, Leicester (?), Rhuddlan, Worcester; to Cambridge those of Chelmsford, Ipswich, Thetford, Yarmouth, Dunwich.

The Carmelite province of England was divided into four distinctiones, namely those of Oxford, London, York, and Norwich, corresponding to the west, south, north, and east districts of England. The first reference to the 'distinction', which seems to have been peculiar to England, is found in the General Constitutions of 1324. It is there enacted that the provision to be made for lecturers and students at the English universities 'shall be made to each from his own distinction and not from another'? From a papal ordinance of 1396 it appears that an equal number of friars was sent to the universities from each distinctio, that friars from the distinctiones of London, York, Norwich, and Oxford proceeded to the degree of B.D. and D.D. from each distinctio in turn and in the order above given, that the four diffinitores elected in every provincial chapter to decide the causes and business of the province were chosen from the four distinctiones-one from each. The pope decreed that in future the provincial prior should be chosen from each distinctio in turn. ${ }^{3}$ The custom with regard to the election of the discreti, who formed a kind of standing executive committee of the provincial chapter, seems peculiar : at any rate I have not found evidence of a similar cuistom among the other mendicent orders. Representatives of each of the distinctiones were consulted on the subject of the reformation of the order in 1446.4 The distinctio was evidently

1 Mon. Ord. Praed. Hist, viii. 187; Cal. Papal Letters, vii. 614; Reliquary, xix 214.

- Zimmerman, Monwmenta Hiotorica Carmalitana, i. 57.

- Cal. of Papal Letters, v. 1 ; cf. p. 18.

Harl. MB. 1819, f. 200. 
of considerable importance in the organization of the Carmelite province. No list of the convents assigned to each of these divisions has yet come to light.

The English province of the Austin friars was divided into five limites. The only information available about them is a list of them with convents belonging to each contained in Harl. MS. 6033 , fol. 57-a miscellaneous collection of notes of the seventeenth century relating partly to the mendicant orders in England. The list, which has no heading and no indication of origin, but obviously from the names of the convents relates to -the Austin friars, gives the following limites and convents :

Limes Oxford: convents of Oxford, London, Bristol, Canterbury, Winchester, Rye.

Limes Lincoln : convents of Lincoln, Boston, Stamford, Northampton, Leicester, Atherston, Grimsby.

Limes Ludlow : convents of Ludlow, Shrewsbury, Stafford, Droitwich, Woodhouse, Newport.

Limes Cambridge: convents of Cambridge, Norwich, Lynn, Clare, Orford, Yarmouth, Thetford, Huntingdon.

Limes York: convents of Hull, Newcastle, Warrington, Tickhill, Penrith.

It will be noticed that the list does not mention convents at Ipswich, Newark, and elsewhere, generally but erroneously included in lists of the Austin friaries.

A. G. Lithle.

\section{The Manuscripts of the Modus Tenendi Parliamentum}

Is a paper read before the Royal Historical Society in 1914 on 'The Authenticity of the Lords' Journals ', 1 Professor Pollard called attention to the fact that a transcript of the Modus Tenendi Parliamentum is prefixed to the manuscript Journals, indicating that the Modus must have been considered authoritative on parliamentary procedure in 1510 ; ho afterwards suggested to us that it might be worth while carefully to examine the text not only of that but of a number of other manuscript copies of it. Forty-seven of these are at the British Museum. ${ }^{2}$ Two, the Cotton MSS. Vespasian B. vii and Nero D. vi, were written towards

1 Traneactions of the Royal Historical Bociety, 3rd ser., viiu. 36. We have to thank Mr. Pollard and Mies Jeffries Davis for help and advice, in the preparation of this peper. We also gratefully acknowledge much aseistance on technical pointe moot kindly given us by Mr. T. Baird Wood and other officisls of the Manuscript Department of the British Museum.

- The descriptive list of manuscripts in M. Bémont's paper, 'La Date de la Composition du Modus Tenendi Parliamentum in Anglia' (Mélanges Julien Havet, 1895, pp. $465 \mathrm{fr}$ ), is incomplete, and ofton erroneous in detail, being mainly baed upon catalogues.

VOL. XXXIV. -NO. CXXXIV. 